\title{
The Fraud Behavior from the Perspectives of the Fraud Triangle: an Indonesian Case
}

\author{
Setya Nugraha ${ }^{\mathrm{a}}$ and Ely Susanto ${ }^{\mathrm{b}}$ \\ aDoctoral Program in Public Administration, Gadjah Mada University, Indonesia \\ ${ }^{b}$ Department of Public Policy and Management, Gadjah Mada University Yogyakarta, \\ Indonesia \\ asetya.nugraha@mail.ugm.ac.id, belysusanto@mail.ugm.ac.id
}

\begin{abstract}
The purpose of this paper is to explore the fraud behavior from the perspective of fraud triangle. Based on the literature review and two samples of the fraud cases, it can be concluded that fraud happens when there are pressure, opportunity, and the rationalization. Sandhu (2016) states that strong ambition, personal financial problem, law problem, family problem includes unsatisfactory with current jobs are indicators that represent the pressure element in the fraud triangle theory. Meanwhile, Sanusi et al. (2015) find that internal control framework relates to opportunity element. Therefore, in the fraud triangle perspective, the opportunity is a loop hole for a fraudmaker in that internal control. The fraudmakers try to maximize their probability in doing the fraud among the existence of the internal control. However, the fraud triangle theory states that although all other two components of the fraud triangle have been existing, if there is not any rationalization in doing the fraud, the fraud will not happen. The two cases that have been explored in the paper confirm the importance of the rationalization as a crucial part of the fraud behavior. The fraudmakers use their justification in order to rationalize their fraud behavior. As the characteristic of the literature review is only focus on the theory and literature, which is limited only to describe the fraud behavior in the theoretical perspective, therefore the future research recommendation is implementing this literature review with the real research, which is exploring the fraud behavior and the rationalization of the fraudmaker by in-depth interview. Another recommendation for the future research is to elaborate the rationalization element of the fraud triangle theory.
\end{abstract}

Keywords: Fraud; Fraud triangle; Pressure; Opportunity; Rationalization; Fraudmaker; Fraud behavior; Justification

\section{Introduction}

The emergence of the research pertaining to fraud around the world has been triggered by the fraud phenomenon in the last decade. Mackevicius and Giriunas (2013) state that fraud has been one of the most negative factors of a society since many years ago. Fraud has been done by a person to take benefits as well as an action that brings disadvantageous other people by doing a deceptive action (Samociuk dan Iyer, 2010). ACFE/The Association of Certified Fraud Examiner (2004) as stated in Diantika (2015) has defined fraud as: 
"the criminal offense of knowingly executing or attempting to execute, a scheme or artifice to defraud a financial institution, or to obtain property owned by or under the control of financial institution, by means of false or fraudulent pretenses, representations or promises.

Fraud has negative effects especially in the public sectors such as decreasing the efficiency, increasing investment cost, and decreasing the government resources (Javaid, 2010). Fraud has also decreased the government income, inhibited the development of a country (Tanwar, 2012), and decreased the public spending portion such as the cost of health, education, and social security (Delavallade, 2006). Based on the consequence of the negative effect of the fraud that makes fraud is something important to manage (Power, 2012), therefore discussing and analyzing the fraud is a strategic and a very important academic research.

The research focus is tax fraud in accordance with the research by Doyle et al. (2009) who state that the tax government officer has been always in the position who decided the amount of tax, therefore they have to cope with the high risk of the fraud. Additionally, the research states that these situations make them in an ethical dilemma as they have to take the final decision on the tax that the auditee should pay (Doyle et al. 2009). The focus of the research is relating to the tax fraud as the tax is the biggest amount of the government income, which achieve $85 \%$ of the Government Budget as stated in the website of the finance ministry on http://www.kemenkeu.go.id/apbn2017.

The tax fraud discussion is relevant for many years as tax fraud can decrease the government income. Torgler (2008) states that the tax fraud can increase externalities cost such as the rising of other tax alternatives that brings heavier burden for the citizen. Tax fraud can switch individual behavior from tax compliance to tax avoidance, the fraud of tax officers, and the change of personal life style (Torgler, 2008). Therefore, the government has to cope with this tax fraud in order to prevent the growing of the tax fraud.

Compin (2015) states that the tax fraud varies from the low level up to the high level such as tax embezzlement, that decreases the government income significantly. Marriottt (2017) states that several classes of the society have more negative images to tax fraud compared to their negative image to general fraud. On the other hand, the self-employed have shown a bigger tolerance to the tax fraud (Marriottt, 2017). The several examples of the tax fraud are tax embezzlement, cost mark up, other income decreasing. The tax fraud cases have been found in Indonesia and many other countries around the world, such as tax fraud in the USA related to several health insurance (Sanders, 2014).

In Indonesia, for the several last years, there are several tax fraud cases that become phenomena that can be explored. The first case, in the year 2010, Gayus had been involved in a money laundering and gratification related to tax assistance to the tax payers with the amount of US\$ 659.800 and Sin\$ 9,68 (Kompas, 2016). The second case, in the year 2013, Herly had been involved in a tax fraud with the amount of Rp6.63 billion (Kompas, 2016). There are still other tax fraud cases, but this paper uses those two tax fraud cases in the background of the research. Based on those phenomena, the literature review has been started with the research question, "Why does the fraud happen?". The literature review is continued to another question, which is, "What do theories say about the fraud behavior?" 


\section{Literature review: the fraud behavior from the perspectives of the fraud triangle theory}

Many researchers that using fraud triangle theory have emphasized behavior aspect in relating unethical behavior (Cohen et al. 2010). Many researchers state that using the fraud triangle in explaining the fraud phenomenon can provide a comprehensive understanding of the fraudmaker motivation and increase fraud eradication program includes prevention, detection, and investigation fraud cases (Dorminey, et al 2012). Cressey $(1950,1953)$ states that fraud happens because of the existence of all fraud triangle elements (pressure, opportunity, and rationalization) as stated by Dorminey, et. al (2012). Ramamoorti (2008) as stated in Dorminey, et al. (2012) state that the fraud research must be performed by integrating people behavior because fraud cannot be separated from people behavior element. The Fraud triangle which consists of pressure, opportunity and rationalization is depicted by Cressey in Mackevicius and Giriunas (2013) as stated in figure 1.

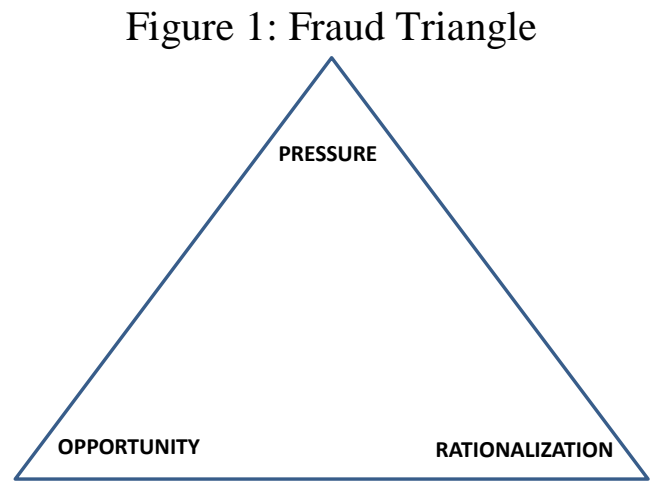

Source: Dellaportas (2012) in Accounting Forum 37 (2013) 29-39

Research related to the fraud triangle has been performed by many researchers, which focus on pressure and opportunity element. Unfortunately, it is still rare for people who research fraud triangle relates to rationalization element (Aghghaleh et al, 2014; American Institute of Certified Public Accountants, 2002). The rationalization is closely related to ethical aspect, and therefore ethics is one of important part in discussing fraud mitigation (Young, 2004). Jondle (2013) also states that although organization value through organizational culture and ethics has been closely related to fraud mitigation, there are not so many research of fraud and ethics. Strawhacker (2016) states that there is a challenge for the future research, which is to explore rationalization of not doing fraud.

Based on the fraud triangle, fraud happened if the three elements, which are pressure, opportunity and rationalization happen at the same time. A fraud maker may have a pressure situation such as the need for money for living cost. Sato (2009) and Huang et al. (2016) state that low salary is one of the causes of the fraud. This is in accordance with the wage efficiency theory that the low salary creates greater fraud risk compared to the high salary (Chaudhuri and Dastidar, 2014; Wu and Ho, 2012). This condition also happens in Indonesia as the employees who have low salaries tend to do the fraud (McLeod, 2008). Sandhu (2016) find that strong ambition, personal financial problem, law problem, family problem includes unsatisfactory with current jobs are indicators that represent the pressure element in the fraud triangle theory. Sanusi et al. (2015) state that internal control framework relates to opportunity element. Therefore, in the fraud triangle perspective, the opportunity is a loop hole for a fraudmaker in 
that internal control. A fraudmaker tries to maximize his/her probability in doing the fraud among the existence of the internal control.

\section{Discussion}

In the case of Gayus, the money laundering and gratification related to tax assistance to the tax payers with the amount of US\$ 659.800 and Sin $\$ 9,68$, it can be clearly seen that he must have a certain situation that becomes their pressure. As we know that Gayus was a government tax officer previously, who also had certain pressures in his life. The criminal justice of the Indonesian government caught and brought back Gayus to Indonesia from his apartment in Singapore. This means that Gayus had a strong ambition to be a very rich people as his pressure in the perspective of the fraud triangle theory (Sandhu, 2016). The expensive price of an apartment in Singapore compared to the Gayus' salary as a civil servant with the grade of III/a does not match the logical principle.

The other case, in the Herly case, who had been involved in a tax fraud with the amount of Rp6.63 billion, he had also a strong ambition to be a very rich people, that can be seen from the huge money (Rp6.63 billion) he had received through his account (Kompas, 2013). Both the cases of Gayus and Herly were different with the finding that the employees who have low salaries tend to do the fraud (McLeod, 2008). Since 2007, the government of Indonesia had improved the salary of the civil servant especially the employees of the finance ministry, an institution of Gayus and Herly before they had been stated as the convicted. The main purpose of this policy is to minimize the risk of the fraud in term of decreasing the pressure factor based on the fraud triangle theory. Gong and Wu (2012) as well as Roden et al. (2016) state that the salary can enhance performance of the employees and decrease the risk of the fraud. Furthermore, the improvement of the salary of the tax officer has been done again in the year 2014 and in the year of 2015 based on the the President Regulation number 37/2015. Therefore, it can be said that the pressure to do the fraud in the case of Herly is different from the finding of McLeod, who states that low salary creates more possibility in doing the fraud. Similar to the case of Gayus, the case of Herly is also triggered by the strong ambition, personal financial problem, and other unsatisfactory with current jobs as Sandhu (2016) said.

The discussion in relation with the second element of the fraud triangle theory, which is the opportunity, is depicted in the following sentences. In the case of Gayus, it can be seen that Gayus had been involved collusion with the tax payer through the tax court. Gayus can execute the loop hole in the process of the tax court by doing the collusion with key persons. The tax court is an institution, which is separated from the finance ministry that has the authority in deciding the dispute of tax cases. As Sanusi et al. (2005) state that this opportunity comes from the weakness of the internal control, therefore this Gayus fraud case happens. Gayus had been proved in the money acceptance of Rp925 million from Roberto related to the tax claim case of PT Metropolitan Retailmart (Kompas, 2016). Gayus has also been proved as the convicted in the case of money acceptance of US\$ 3.5 million from Alif Kuncoro related with other tax claim cases (Kompas, 2016).

Meanwhile, in the other case, Herly can also execute the opportunity of doing the fraud. Based on the verdict of the court, Herly had been proven as the convicted in the gratification case with the amount of Rp6.63 billion for his act of decreasing the amount of the taxes that had been paid by PT Mutiara Virgo (Kompas, 2013). This opportunity is in accordance with 
the statement of Doyle et al. (2009) who state that the tax government officer has been always in the position who decided the amount of tax, therefore they have to cope with the high risk of the fraud. This situation creates an opportunity for the fraud maker as they can execute the loop hole in determining the tax amount of the tax payers. Therefore, both the two cases happen in the existence of the opportunity to do the fraud. In the Gayus case, there had been the possibility to win the tax payers of their tax claim and the possibility to get the gratification as the "reward" from the taxpayers to Gayus. Meanwhile, in the case of Herly, there had been the possibility of receiving a sum amount of money as the gratification.

Schuchter and Levi (2016) state that the pressure and the opportunity in fraud triangle are the important elements in term of institution perspective as the factors that support the fraud behavior. However, the rationalization, which is the third element of the fraud, is the important factors of the fraud behavior because even though the opportunity and pressure element has been existing, the fraudmaker has to rationalize his/her fraud behavior (Murphy dan Dacin, 2011). Jackson, et al. (2010) in Sandhu (2016) state that the rationalization is related to the justification of the fraudmaker to their unethical and corrupt behavior. Furthermore, based on those research, both the people who have high morality and people who belong to an immoral person will justify their fraud behavior before they execute the fraud. The justification process is much more difficult for the high morality compares to the immoral person (Jackson, et al. 2010 in Sandhu,2016). Schuchter and Levi (2015) find that the rationalization in the fraud triangle has been influenced by the internal condition of the organization such as the organizational culture.

Murphy and Dacin (2011) state that when there have been both the pressure and the opportunity, the fraudmaker has to win the dynamics process before doing the fraud. The people who commit the fraud uses their rationalization in order to eliminate the negative effect of the unethical behavior (Murphy and Dacin, 2011). Chen, et al. (2014) state that the pressure and the opportunity have been influenced by the external factors, meanwhile the rationalization has been influenced by the internal factors, which are a psychological aspect and cultural factors. Therefore, the rationalization becomes the most important factor in controlling the fraud risk, as stated by Snell (2009) who emphasized on empowering tools for the employees by providing ways to recognize ethical dilemma, and therefore the employees can make a right decision. Snell (2009) also states that it is important to set up a clear ethical limitation, that is useful for the standing point for the employees to cope with the fraud ethical dilemma. Bejarano (2008) states that the better research of the fraud is only if its focus is on the individual behavior aspect. Based on the fraud triangle theory, both the cases of Gayus and Herly, they had to cope with their ethical dilemma whether to do the fraud or not. However, both the two cases, finally, they decided to do the fraud and neglect their ethical dilemma. In the case of Gayus, he also did the money laundering to legitimate their illegitimate money. Clark and Tigue (1975) in Alasmari (2012) state that money laundering is an old technique to legitimize the illegitimate money into the formal financial system so that it becomes legitimate. Ehrenfeld (1992) also in Alasmari (2012) state that the process of the money laundering involves integrating the illegitimate money into formal financial systems and normal businesses. The people who did the money laundering laundered the illegitimate money, so the money cannot be traced back to the original crimes (Alasmari, 2012). In the case of Gayus, he did the money laundering by buying several high price property including an apartment in Singapore. 
Meanwhile, in the case of Herly, he tried to set the new business through PT Mitra Modern Mobilindo (Kompas, 2013). The money laundering they did proves that they had been involved in an ethical dilemma as they realize that their money in those cases was not illegitimate money. Both the two cases involve the process of the rationalization in winning their reasons to do the fraud. However, what is their rationalization in both two cases had not been the focus of this paper, therefore it will become a topic to be researched in the future.

Lesson learned from this paper, which is related to the fraud behavior in the perspective of the fraud triangle theory, fraud happens because of the existence of all the three elements (pressure, opportunity and rationalization). However, the rationalization is the most important element in the process of the fraud doing. Although there have been some certain pressures and an opportunity in doing the fraud, it still needs the rationalization for a fraudmaker before he/she commits the fraud. In other words, the rationalization of the fraud maker becomes the crucial factor in determining the existence of the fraud as Cohen et al. (2010) stated in his research. Unfortunately, the reserch that focus in the rationalization element has not been done by many researchers. Aghghaleh et al. (2014) state that this condition has been caused by the difficulty in finding the indicators of the rationalization element.

\section{Conclusions}

Based on the reviewing the literature and comparing with the two cases, it can be concluded that fraud happens when there is pressure, opportunity, and the rationalization. Although all the two components of the fraud triangle theory have been existing, if there is not any rationalization in doing the fraud, the fraud will not happen. The fraud makers use their justification in order to rationalize the fraud behavior.

\section{The future research recommendation}

As the characteristic of the literature review is only focus on the theory and literature without interviewing the fraudmaker, therefore the future research recommendation is implementing this paper with the real research. The real research will explore the rationalization of the fraud maker by in-depth interview and hence, it will describe the real situation of the fraudmaker comprehensively. Another recommendation for the future research is to elaborate the rationalization element of the fraud triangle theory.

\section{References}

Aghghaleh, S.F., Iskandar, T.M., \& Mohamed, Z.M. (2014). Fraud risk factors of fraud triangle and the likelihood of fraud occurrence: evidence from Malaysia. Information Management and Business Review, 6(1), 1-7.

Alasmari, K.A. (2012). Cleaning up dirty money: The illegal narcotics trade and money laundering. Economics \& Sociology, 5(2A), 139-148,162.

Bejarano, J.R. (2008). Mitigating corporate financial fraud: a qualitative study. University of Phoenix Scholl of Advance Studies.

Chen, J., Cumming, D., Hou, W., \& Lee, Edward. (2014). Does the external monitoring effect of financial: analysts deter corporate fraud in China? Journal of Business Ethics, 134, 727-742. doi: 10.1007/s10551-014-2393-3 
Dellaportas, S. (2013). Conversations with inmate accountants: Motivation, opportunity and the fraud triangle. Accounting Forum, 37, 29- 39. doi: 10.1016/j.accfor.2012.09.003

Delavallade, C. (2006). Corruption and distribution of public spending in developing countries. Journal of Economics and Finance, 30 (2), 222-239.

Diantika, A. (2015). Analysis of micro banking policy: a case study of fraud and controlling to Bank Perkreditan Rakyat (BPR) in Indonesia. Fisipol, Gadjah Mada University.

Dorminey, J.W., Fleming, A.S., Kranacher, M.J., \& Riley, R.A. (2010). Beyond the fraud triangle: Enhancing deterrence of economic crimes. The CPA Journal, 80(7), 17-23.

Dorminey, J.W., Fleming, A.S., Kranacher, M.J., \& Riley, R.A. (2012). The evolution of fraud theory. Issues in Accounting Education, 27(2), 555-579. doi: 10.2308/iace-50131

Doyle, E.M., Hughes, J.F., \& Glaister, K.W. (2009). Linking ethics and risk management in taxation: Evidence from an exploratory study in Ireland and the UK. Journal of Business Ethics, 86,177-198. doi: 10.1007/s10551-008-9842-9

Ichwan, A. (2013, August 7). How long has Gayus been in the jail?. The Kompas. Retrieved from http://nasional.kompas.com/read/2013/08/07/1151174/

Javaid, U. (2010). Corruption and its deep impact on good governance in Pakistan. Pakistan Economic and Social Review, 48(1), 123-134.

Jondle, D., Maines, T.D., Burke, M.R., \& Young, P. (2013). Modern risk management through the lens of the ethical organizational culture. Risk Management, 15(1), 32-49.

Lumbanrau, R.E. (2016, November 23). List of tax fraud. The CNN Indonesia. Retrieved from http://www.cnnindonesia.com/nasional/20161122162351-12-174492/rentetan-kasuskorupsi-yang-menjerat-pegawai-pajak/

Mackevicius, J., \& Giriunas, L. (2013). Transformational research of the fraud triangle. Faculty of Economics, Vilnius University, 92(4), 150-163.

Maharani, D. (2013, February 18). Herly, Dhana Widyatmika's friend, has accepted 6 years imprisonment. The Kompas. Retrieved from https://nasional.kompas.com/read/2013/02/18/21385385/Herly.Rekan.Dhana.Widyat mika.Divonis.Enam.Tahun.Penjara

Murphy, P., \& Dacin, T. (2011). Psychological pathways to fraud: Understanding and preventing fraud in organizations. Journal of Business Ethics, 101(4),601-618

Nugroho, S.B.M. (2014, April 27). Tax fraud pattern. [Web log post]. Retrieved from http://nugroho-sbm.blogspot.co.id/2014/04/pola-korupsi-pajak.html

Power, M. (2012). The apparatus of fraud risk. Accounting, Organizations, and Society,38,525543 doi:10.1016/j.aos.2012.07.004

Rahmi, N. \& Salmande, A. (2012, February 24). Gayus tax fraud case has been repeated. The Hukum Online. Retrieved from http://www.hukumonline.com/berita/baca/lt4f47bf2d814c2/kasus-gayus-terulang-lagidi-ditjen-pajak

Samociuk, N., \& Iyer, N. (2010). A short guide to fraud risk: Fraud resistance and detection. England: Gower Publishing Limited.

Schuchter, A., Levi, M. (2016). The fraud triangle revisited. Security Journal, 29(2), 107-121.

Snell, R. (2009). Cynthia Cooper discusses fraud, ethics, and standing up for what's right. Journal of Health Care Compliance, 11(5), 37. 
Strawhacker,J.C. (2016). Analysis of factors influencing corporate ethics and anti-fraud programs. ProQuest LLC.

Susanto, E. (2009). Understanding of corruption based on organization behavior perception: Why people are getting trapped in the fraud behavior? Journal of Public Policy and Administration, 13(1), 18-30.

Tanwar, G. (2012). Corruption and its impact on development: a cross-national study. Faculty of the Graduate School of Arts and Sciences of Georgetown University.

Young, P.C. (2004). Ethics and Risk Management: Building a Framework. Risk Management, $6(3), 23-34$. 